\section{RELACIO $\wedge$ ES}

Relaciones. Estudios de historia y sociedad ISSN: 0185-3929

relacion@colmich.edu.mx

El Colegio de Michoacán, A.C

México

Argueta Villamar, Arturo; Castilleja González, Aída

Las uauapu en la vida de los p'urhépecha o tarascos de Michoacán

Relaciones. Estudios de historia y sociedad, vol. XXXIII, núm. 131, 2012, pp. 283-320

El Colegio de Michoacán, A.C

Zamora, México

Disponible en: http://www.redalyc.org/articulo.oa?id=13725131007

- Cómo citar el artículo

- Número completo

- Más información del artículo

Página de la revista en redalyc.org

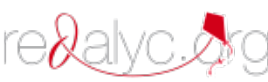

Sistema de Información Científica

Red de Revistas Científicas de América Latina, el Caribe, España y Portugal

Proyecto académico sin fines de lucro, desarrollado bajo la iniciativa de acceso abierto 


\title{
Las uauapu en la vida de los p'urhépecha o tarascos de Michoacán
}

\author{
Arturo Argueta Villamar* \\ UNAM \\ Aída Castilleja González \\ INAH
}

Con base en registros de campo realizados durante los últimos diez años en diversos pueblos p'urhépecha se presentan los elementos de lo que hemos denominado Complejo Uauapu, que incluye un conjunto de conocimientos, creencias y prácticas en torno a las abejas silvestres que habitan distintos nichos ecológicos. La recurrencia de ciertos elementos entre los pueblos estudiados sugiere interesantes vías de comparación que evidencian la importancia de estos insectos sociales en la vida actual de los p'urhépecha.

(Uauapu, abejas, ceremonias, conocimientos, p’urhépecha, Michoacán).

\section{INTRODUCCIÓN}

1 contrastar algunos de los primeros testimonios y notas de campo que obtuvimos en nuestro trabajo en distintos pueblos de la sierra p'urhépecha, con lo reportado en diversos estudios sobre la relevancia social y cultural de las abejas silvestres sin aguijón, todo hacía pensar que estábamos frente a un caso más de las complejas relaciones entre estas abejas y los pueblos mesoamericanos. Sin embargo, al hacer la colecta de ejemplares para identifi-

* (arguetav@unam.mx) (aidacastilleja@prodigy.net.mx) Los autores agradecen las observaciones, comentarios y contribuciones de Moisés Franco Mendoza, Ismael García Marcelino y Pedro Márquez Joaquín, expertos conocedores y orgullosos continuadores de la cultura p'urhépecha. Agradecemos también a la Mtra. Beatriz Rodríguez, en el Instituto de Biología de la UNAM, por la identificación biológica de los ejemplares. Nuestro agradecimiento también a quienes anónimamente dictaminaron el artículo para esta publicación pues sus observaciones enriquecieron y dieron mayor precisión al texto. 
carlas en el laboratorio, el primer piquete evidenció que nuestras uauapu no eran abejas sin aguijón sino avispas con aguijón.

El hecho en sí, lejos de desanimarnos por no estar en presencia de las mejor conocidas Xunan kab (Melipona becheii) de Yucatán y el área maya, Puebla y Veracruz, nos condujo, en primer lugar, a analizar, en forma comparada, las interrelaciones que los pueblos indígenas establecen con los insectos sociales, independientemente de si son abejas o avispas; en segundo lugar, a denominar a nuestras avispas o uauapu (Polybia spp. $)^{1}$ como abejas, pues es así como se les conoce en los pueblos de la región estudiada; y, en tercer lugar, a estudiar en profundidad un tema que ha pasado un poco desapercibido en la literatura histórica, antropológica y etnozoológica de la región: la importancia de las abejas, la miel y los panales en la vida social y en la cultura p'urhépecha de Michoacán.

En este artículo, el primero de una serie, expondremos tres aspectos del tema señalado. En el primero presentaremos algunos elementos de carácter general en torno al Complejo Uauapu; en el segundo nos centramos en la exposición de saberes y prácticas en torno a las uаuapu; y en el tercero abordaremos el despliegue ritual en el que se expresa el Complejo Uauapu en la vida ceremonial, específicamente en la llamada Bajada de los Panaleros que se lleva a cabo en el pueblo serrano de Cherán en la víspera de la fiesta del Corpus Christi y la Cha'nantskwa. ${ }^{2}$ Finalizamos con algunas reflexiones, entre las que

${ }^{1}$ El avance actual en la identificación biológica de nuestras abejas-avispas, fue realizado por la Mtra. Beatriz Rodríguez, del Instituto de Biología de la UnAM, con base en claves de la familia, es el siguiente: Familia: Vespidae; Subfamilia: Polistinae; Tribu: Epiponini; Género: Polybia. Un esfuerzo anterior nos ofreció los siguientes datos: Órden: Hymenoptera; Familia: Vespidae; Género: Polistes; Especie: Polistes metricus Say, a partir de tal identificación revisamos decenas de fotos, distribución geográfica y formas de los nidos y concluimos que Polistes metricus Say es distinta a nuestras uauapu en tamaño, forma y coloración y los nidos son distintos en forma y tamaño.

${ }^{2}$ Es interesante hacer notar que en esta celebración se fusionan dos sentidos: el asignado por la liturgia católica que marca al Corpus Christi como una de las celebraciones centrales en cuanto que corresponde a la eucaristía y, por lo tanto, a la transubstanciación del cuerpo de Cristo y, por otra parte, el sentido propiciatorio y de fertilidad con que se reconoce a esta celebración en los pueblos de la región. En esta celebración también se expresa la importancia que tiene el intercambio en distintos niveles: con la divinidad, entre miembros de una misma comunidad y entre comunidades vecinas. Es un intercambio que, entre personas, toma una forma lúdica, sobre todo después de concluida la 
destacan las perspectivas con las cuales nuestro estudio, y particularmente este texto, pretenden dialogar: la perspectiva etnoecológica planteada para explicar de manera holística los saberes y los haceres relacionados con una matriz cultural (Toledo 1992; Toledo y Barrera 2008); la perspectiva del estudio de las ontologías indígenas que señala la necesidad de no escindir o dicotomizar las complejas relaciones entre el orden de lo humano y de lo no humano ${ }^{3}$ como vía para explicar mejor las intrincadas relaciones entre cultura y naturaleza (Descola 2001, 101 y ss; 2005); y la perspectiva de la ecología política y los estudios ambientales, que reconocen en los conocimientos locales y colectivos otras maneras de abordar la conservación de la biodiversidad y el manejo de los recursos naturales, como alternativas que adquieren cada vez mayor importancia en el mundo actual (Nygren 1999; Durand 2008 y Argueta 2008).

Cuando hablamos del Complejo Uauapu nos referimos a un conjunto de elementos integrado por abejas, miel, larvas, los conocimientos, prácticas y creencias involucrados en su aprovechamiento y vinculados también a los bosques donde se producen y reproducen, así como el papel que todo ello tiene en la vida social de los p'urhépecha que tiene una función relevante en el ámbito ritual. Complejo que se ha configurado históricamente y se expresa en una interesante gama de variantes locales en la geografía regional, en las cuales las relaciones de parentesco, pertenencia socioterritorial o de adscripción a algún oficio siempre están presentes.

Las uauapu son insectos sociales, silvestres, no domesticados, que habitan las montańas del centro de Michoacán. En el contexto ceremonial se establecen relaciones a través de agrupaciones de hombres de distintas generaciones llamados a sí mismos panaleros; éstos se dan a la tarea de colectar panales para integrarlos en distin-

procesión solemne. El término Chan'antskwa, con el que también se refiere a esta celebración alude al rejuego, en tanto que es algo que se da una y otra vez; con este término también se denomina al Carnaval.

${ }^{3} \mathrm{Al}$ hablar del orden de lo no humano nos referimos a concepciones vinculadas al carácter sagrado y animado de la naturaleza que podríamos también distinguir como extrahumano. Un orden del mundo, que tiene un orden jerárquico por encima de lo humano con el cual se establecen interacciones de muy diversa índole. 
tos momentos del ciclo ritual a lo largo del año. En estas agrupaciones las relaciones de parentesco y de vecindad ocupan un lugar importante; las modalidades actuales de su participación, lo mismo que las de los cazadores, permiten considerarlos como oficios fundamentalmente rituales.

Hoy en día, el beneficio económico que los panaleros y sus familias obtienen a partir de la miel silvestre o de la venta de los panales es de importancia secundaria; sin embargo, es muy importante el contexto ritual en el que se despliegan sus actividades ya que pone el acento en un intrincado sistema de intercambio y reciprocidad en el que el Complejo Uauapu se configura mostrando una multiplicidad de aristas que lo hacen muy interesante para reflexionar sobre el campo de las interrelaciones sociedad-naturaleza, cultura-naturaleza. Los panaleros se distinguen claramente de los apicultores cuya actividad está orientada al cultivo de las abejas de origen europeo (Apis melifera) y a la obtención de miel, cera y otros productos, para su comercio en los mercados local y regional.

A partir de lo que aquí exponemos, revisamos algunas explicaciones en torno a los sistemas de conocimientos y prácticas de los p'urhépecha. Así mismo, se trazan algunos paralelismos respecto a otros pueblos de México y del mundo, en cuanto a las especificidades y similitudes de las relaciones entre humanos y algunas especies de insectos sociales.

Respecto al escenario debemos decir que el P'urheecherio o región p’urhépecha, abarca una amplia porción del territorio estatal de Michoacán, cuya extensión aproximada es de $6,000 \mathrm{~km}^{2}$. En él se distribuyen más de una veintena de los 113 municipios del estado de Michoacán, en los que se concentra la gran mayoría de los 120,000 hablantes de lengua p'urhépecha, lengua que, no está de más recordarlo, se distingue por no tener filiación alguna con otra lengua indígena del territorio nacional. Además de su definición como región natural, que constituye la subprovincia neovolcánica tarasca del Eje Neovolcánico Transversal, su configuración histórica, su diversidad cultural y los procesos sociales que la han constituido permiten también hablar de ella en términos de región cultural (Castilleja 2001, 24; 33). 
Sierras, lomeríos, valles segmentados, planicies aluviales y lagos, así como numerosos pueblos, ranchos y ciudades entre los cuales existen estrechas vecindades, arreglos jerarquizados y relaciones de intercambio, configuran un paisaje cultural que, desde diversas disciplinas, ha sido objeto de múltiples estudios desde hace más de una centuria. Esta condición de diversidad ha ido aparejada a la generación de identidades en su interior, como lo indica la tensión que existe entre la identidad comunitaria y aquellas que se generan en ámbitos de mayor inclusión. Es así que, además de sus diferencias en términos del medio natural, en su interior se reconocen subdivisiones, asociadas a sentidos de pertenencia y autoadscripción, que tienen distinta extensión y composición por las características y número de pueblos agrupados en cada una: Eráxamani (Cañada de los Once Pueblos), Japondarhu (la zona lacustre que incluye a Pátzcuaro y a Zirahuén), Juatarhu (la sierra o meseta) y Tsirontarhu (Ciénega de Zacapu) (Argueta 2008, 26).

\section{LA OBTENCIÓN DE MIEL Y DE PANALES: UN OFICIO DE TIEMPO ATRÁS}

La Relación de Michoacán $(R M)^{4}$, fuente por excelencia del siglo XVI para conocer la organización y forma de gobierno de los tarascos al momento del contacto, aporta datos en torno a la miel y los panales. En el relato sobre la manera en la que chichimecas e isleños conquistaron toda la provincia, se detallan nombres de lugares y se hace mención del Cuypu hoato que se traduce como cerro de panales (Alcalá 2000, 525) y el Diccionario Grande de la Lengua de Michoacán $(D G)^{5}$ (cerca 1560-1561, 138) nos ofrece otro topónimo relacionado que es el de Cuipuendo (lugar de los panales).

Es interesante destacar que en $R M$, en los capítulos sobre las funciones del gobierno, se habla del Kuipacuri, un mayordomo que, de

${ }^{4}$ Relación de las cerimonias y rictos y población y gobernación de los indios de la provincia de Mechuacan. El autor fue fray Jerónimo de Alcalá, quien lo elaboró, acompañado de especialistas nativos, complementándolo con 44 láminas.

${ }^{5}$ Anónimo(s), Diccionario Grande de Michoacán, 1991. Aquí lo citaremos como DG. 
manera específica, se encargaba de "recibir y guardar toda la miel de caña de maíz, de abejas y abejorros, que traían al cazonci”. ${ }^{6}$ Este funcionario, de manera similar a otros de la misma jerarquía, estaba vinculado al ocámbecha, encargado - entre otros asuntos-del conteo de la gente y del tributo; formaba parte del cuerpo de diputados y mayordomos de alta jerarquía por estar al mando directo del cazonci. ${ }^{7}$

En el capítulo titulado "De la gobernación que tenía y tiene esta gente entre sí”, cuando se describen las funciones asignadas a los diputados y mayordomos, se distinguen posiciones y funciones especializadas que, con claridad, dejan ver el carácter complementario que tenían los oficios vinculados al dominio de los cerros y particularmente con la obligación de mantener el abasto constante de la leña para arder en los templos o cúes, con aquellos orientados a la producción agrícola y artesanal, así como otros de carácter fundamentalmente ritual. Así, por ejemplo, se anota la que correspondía a un funcionario que guardaba las águilas grandes, había otros que se distinguían por ser quienes "suben a lo alto", o el quanícoti, cazador mayor, diputado sobre todos los de este oficio acotando que, al tiempo de escribirse la $R M$, aún había muchos "con uno que los tiene a su cargo" (Alcalá 2000, 559-563).

Estas especializaciones y la jerarquía de quienes las encabezaban son similares a la importancia de los dos oficios actuales - panaleros y cazadores-que adquieren carácter ritual en la celebración anual del Corpus, asunto que revisaremos con mayor detalle más adelante. Es probable que paralelismos como éste, constituyan una de las bases del sentido emblemático con el que llega a equipararse la fiesta del Corpus con la que -según lo expresó una persona en Pamatácuaro hace unos años- celebraban en honor a Cueravperi, divinidad creadora por excelencia. ${ }^{8}$

${ }^{6}$ Relación de ceremonias... 176; Cazonci es el nombre que daban los tarascos o p'urhépecha al dignatario principal de todo el P'urhepecherio.

${ }^{7}$ Sepúlveda seńala la importancia que tenía la miel como tributo (Sepúlveda 2003, 59).

${ }^{8}$ Identificamos un sentido similar cuando al escuchar la pieza musical distintiva del Corpus en Ihuatzio se explicaba que con ella se pide la lluvia. 


\section{LAS UAUAPU: CONSTRUCTORAS DE PANALES, HACEDORAS DE MIEL}

Los p’urépecha hablantes entrevistados coincidieron en señalar que en su idioma se llaman uauapu, cuando las nombran en español las denominan como abejas, distinguiéndolas de las europeas que se cultivan en cajones a las que llaman colmenas. Las uauapu (o moxquito pequeño, como lo traduce el $D G(1991,690)$ hacen panales, producen miel y tienen aguijón, entre otras características.

Aunque uauapu es el nombre genérico para estos insectos sociales, reconocen diferencias en función de sus características morfológicas (tamaño y color), de su comportamiento (agresividad o intensidad del piquete) y de las características de sus panales (tamaños, colores y distribución), de hecho, podemos decir, que en las entrevistas estaban claramente relacionadas las características de los tipos de иаиари con las de los panales. Ismael García Marcelino nos dice que las uаиари, о иари para algunos pueblos de la sierra, son las abejitas negras y pequeñas, las tsitsisï son las avispas rojas grandes, el khapari es el abejorro, grande, amarillo y con bandas negras. Hay otro más que es el jesïy en Ihuatzio hay una avispa negra, más chiquita que el uauapu que se llama tsikapu. ${ }^{9}$ También suelen diferenciarlas en función del área donde habitan y de las cualidades de la miel. Las que viven en bosques de mayor altitud son más chicas y la miel es más sabrosa, coincidiendo con las áreas donde se distribuye una importante proporción de pueblos de la región. Hay mieles más acuosas que otras y las más espesas gustan más.

En el $D G$ encontramos los siguientes términos: Cuipu (panal de árboles siluestre), Cuipu hatzicuni (Hazer panal siluestre las auejas), Cuipu hatzicucha (auejas silvestres) y Cuipu acuni o picuni (coger estos panales silvestres), lo que refuerza la idea de la antigüedad del conocimiento de los panales y la miel silvestres y de la existencia de los panaleros, los Khuipu acuni $(1991,137)$.

${ }^{9}$ La identificación biológica y las relaciones entre estos insectos se expondrán con detalle en el artículo correspondiente a los saberes y prácticas en torno a las uauapu. 




Fото i. Panales colectados por panaleros de Cherán (2008). Todas las fotos de este artículo son de Aída Castilleja González.

Predomina el uso genérico de nombre panal o khuipu, aunque algunas diferencias entre ellos se traducen en nombres distintos. El panal está hecho de tierra, agua, fragmentos de flores, hojas y corteza. A las uauapu les gusta morder la corteza del madroño o panangsï (Arbutus xalapensis) ya que la masa que obtienen de ella es más resistente y maleable.

Al nombre de panal o khuipu, suelen agregar algún calificativo con el que destacan alguna de sus propiedades. Los distinguen según el tamaño, forma y color, así como por el tamaño y color de las uauapuecha que lo hacen y el sabor de la miel. Estas distinciones también corresponden a su distribución en la geografía regional. Al inquirir sobre la procedencia de los panales, la información es rica en cuanto al reconocimiento de lugares y características del entorno, tanto en el ámbito de la región, como de áreas vecinas hasta donde remontan tras la búsqueda de estos panales.

Los panales más comunes son los ovalados, aunque los hay redondos y otros en cuya parte superior es ligeramente más angosta 
que su base. Aunque el color más común es el gris, también los hay cafés y rojizos. El tamaño es variable, desde 15 a $20 \mathrm{~cm}$ de largo por 25 a $30 \mathrm{~cm}$ de ancho, hasta los muy grandes de $1 \mathrm{~m}$ de largo por 40 a $50 \mathrm{~cm}$ de ancho.

Los panales colorados suelen tener más miel por lo que son más pesados, tienen pocas larvas y las uauapu son de color charápiti o rojizas, éstas son de tierra caliente por lo que pocas veces anidan en tierras cercanas a Cherán y siempre regresan a su lugar de procedencia (de Uruapan o La Huacana, hacia la zona de tierra caliente, en el sur de Michoacán). Las uauapuecha que hacen panales grises son más turipiti o negras u oscuras.

La procedencia de los panales también es un criterio de distinción y comparación: "los de por Patamban aunque son más grandes, son más bofos y no están tan buenos como los de Cherán. En los de Cherán la telita que está sobre las larvas es más gruesa”.

El uaricho es un panal negro que crece entre los arbustos, las abejas son más grandes y más bravas, pero la miel es más sabrosa. $\mathrm{Al}$ panal más grande lo llaman alamu o arhamu, ${ }^{10}$ que suele ser de forma cónica y de color gris; éste es el que colocarán en la parte superior de la katárhakwa. Además de las características enunciadas, a los panales se les reconocen otras propiedades. Entre los panales más pequeños distinguen aquellos que ya no han de crecer; de ellos se dice que son xépiti, flojo o "panal huevón".

La búsqueda de panales va aparejada a la habilidad de avistamiento de los panaleros, pero también es cuestión de suerte. Entre ellos reconocen que quien tiene la fortuna de encontrar el arhamu, será aquel que en alguna de las jornadas previas de búsqueda, hu-

${ }^{10}$ La palabra arhá hace alusión a algo que se raja, así suelen decir cuando se hacen una cortada en la boca, distinguiéndolo de la abertura de la boca; otro de los sentidos de este término hace alusión a los órganos sexuales externos de la mujer. En otra explicación, el término parece tener correspondencia con el verbo arhani acompañado del morfema mu que se refiere a la boca (Alicia Mateo, Cuanajo, comunicación personal, 2009). El verbo arhani (Velásquez 1978, 110) significa rajar, abrir, pero también está relacionado con devorar o emborrachar. Para Swadesh $(1969,59)$ el término arhá también tiene los anteriores significados, pero aparece otro que puede tener mejor relación con el objeto analizado, que es el de arháhchakumani (que traduce como rebasar) o arháhtarikua (paso largo) o arháhkuri (una cuarta), es decir, con denominaciones de medida. 
biese visto un panal pequeño, en formación y, por lo tanto, totalmente cubierto de uauapuecha. A este panal algunos lo reconocen como japingua, que entre los p'urhépecha es una entidad territorial, dueña de ciertos animales, que reside en los bosques; suelen reconocérsele cualidades contrastantes, pudiendo ser fastas o nefastas. Por ello, para los panaleros, y en el contexto de su participación en el ceremonial, encontrar un panal de este tipo lo consideran como un "aviso" que, sin duda, les trae buena suerte ya que después encontrarán el arhamu y al lucir un panal así de grande en su katárakwa obtendrá el reconocimiento y prestigio de ser buen panalero, capaz y conocedor. ${ }^{11}$

Los panales pequeños son seleccionados para llevarlos, a manera de ofrenda, a la imagen de San Antelmo ante quien presentaron sus peticiones de protección y ayuda antes de salir a la búsqueda de los panales. Otros, también pequeños, los separan para armar la katárakwa de los niños más pequeños - generalmente hijos de alguno de los panaleros- que habrán de acompañarlos en el recorrido por el pueblo en la víspera de la celebración del Corpus.

La miel es considerada un rico alimento, no sólo por su sabor, sino por sus propiedades alimenticias y es también utilizada en procedimientos terapéuticos, como por ejemplo, dada la pureza y la limpieza de la miel, se le usa como antiséptico y cicatrizante. No hay registros, ni hemos encontrado algo que indique la elaboración de alguna bebida a partir de la miel de las uauapu, pero los panaleros reconocen que esta miel, cuando parten el panal para comer en pedazos, escupiendo después el bagazo, llega a "atarantarlos" por la gran cantidad de azúcar que tiene; esta sensación también la asocian al consumo de las larvas. Testimonios como éste sobre "la fuerza de la miel" y las descripciones en torno a la búsqueda de panales, son

${ }^{11}$ Pedro Márquez subraya que su concepto de japingua es el de riqueza, o de los bienes habidos por los seres divinos invisibles y subraya que no olvidemos que la japingua se transforma en animal. En tal sentido, agregamos nosotros, japingua es un ser no humano, que contiene las potencialidades de transformación que, según señala la $R M$, tenían varias deidades como es el caso del Thiuime (la ardilla), que puede tomar forma este animal pero también "se volvía sol, luna, estrella, águila, halcón, pájaro, aires, fuentes de agua, árbol, pescado, todo esto mostró” (véase Argueta 2008, 75). 
parte de las explicaciones respecto a la formación, características y distribución de los panales, lo que conlleva conocimientos precisos sobre el comportamiento y elementos distintivos de las uauapu y de las relaciones con el entorno del que forman parte.

La miel de las uauapu es rica, pero hay otras mieles silvestres procedentes, por ejemplo, de las abejas denominadas khapari y se distingue del abejorro que es el uanapu khéri (véase Velásquez 1978, 220). Dice Pedro Márquez que los khapari son una abejas silvestres que generalmente producen su khuipu en los malpaises, y que por estar abajo de las piedras casi siempre se destruyen para sacar la miel. Pero al igual que en los khuipu de las uauapu producen larvas y que tanto las larvas de uauapu como del khapari son un alimento privilegiado para la gente. Señala también que la picadura del khapari produce un dolor más intenso que la picadura de uauapu, el khapari es mucho más grande, pero el paralelismo entre las dos es su carácter medicinal ya que ambas se utilizan en el tratamiento del reumatismo (Comunicación personal, 2009).

\section{EL PANAL Y EL MUNDO}

Sea como metáfora o metonimia, las descripciones que hemos registrado sobre el panal hablan de la forma del mundo, de lo que contiene, de lo que lo delimita y relaciona con otros componentes de su entorno. Los testimonios que hemos recabado hablan de una estrechísima relación entre el panal y el mundo; el panal y la vida social; ${ }^{12}$ la fertilidad, lo femenino y lo masculino.

Khuipu es una palabra para nombrar el panal y con este mismo término se nombra a la vagina; resulta por demás interesante que -según comentó Moisés Franco en comunicación personal- esta voz también refiere al falo por lo que el panal se constituiría como una dualidad que abarca lo femenino y lo masculino. El panal tiene

${ }^{12}$ Es interesante hacer notar que Franco (1994) analiza distintos significados de la voz sïruki, y destaca que uno de ellos es el de hormiga. En tanto que el interés del autor está centrado en el concepto de tradición, plantea analogías por demás sugerentes entre estos insectos que, como las abejas, las avispas o las termitas, también son insectos sociales, es decir, se caracterizan por tener organización, orden y pertenencia. 


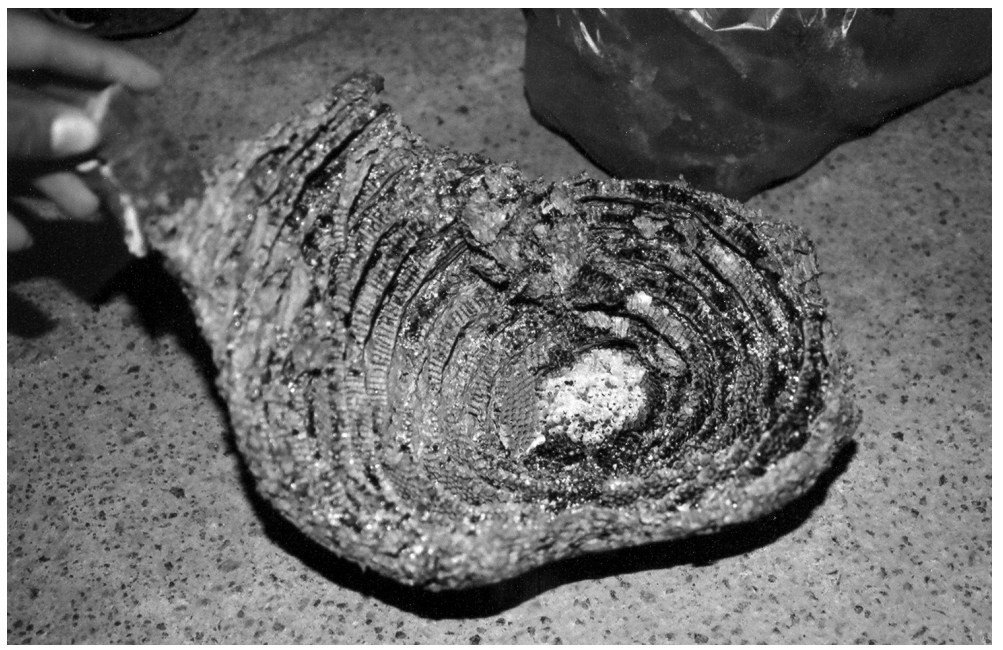

Fото 2. Corte transversal del panal que muestra el ombligo y la "natita”.

también ombligo y tiene un ojo. En el panal, a manera de vientre, está la reproducción.

Adelaida Cucué, de Cherán, nos hizo saber que su abuela (de quien ella aprendió la manera de curar), le explicó que el panal es "mero el mundo, ahí está todo" . ${ }^{13}$ Está formado por un centro, al que también llaman ombligo y "ya de ahí se van haciendo las distintas capitas donde están las larvas y de donde salen las abejitas”; esta parte suele estar cubierta por una delgada capa blanca a la que llaman "natita" y es ahí donde radica la mayor fuerza del panal. Este centro es reservado para darlo a comer a algún niño de corta edad. ${ }^{14}$

Si bien se reconoce la importancia de la uauapu reina en la formación de los enjambres, también intervienen otros conocimientos

${ }^{13}$ Para los Awa de Colombia, las meliponas o abejas sin aguijón, "son hijas del sol, seres que favorecen la fertilidad, así como los comienzos y la continuidad de la vida, tanto en tiempos ancestrales como en la vida social. Las abejas están en la base de la vida misma" (véase Ana María Flachetti y Guiomar Nates-Parra 2002, 175).

${ }^{14}$ Este testimonio concuerda ampliamente con lo que se seńala para los masai, un pueblo africano: "Entre los masai, del sur de Tanzania, la miel sólo era consumida por niños. En otros tiempos fue el alimento principal de los guerreros y de quienes iban de cacería. Las larvas se reservaban para los ancianos" (Fischer 2007). 
y concepciones en la explicación de la formación de nuevos nidos. Estas explicaciones giran en torno al tamaño del enjambre y a la necesidad de multiplicarse, como si se tratase de una familia, de un pueblo. Proceso que inicia con la formación y crecimiento de un nido $y$, en un segundo momento, con la división y formación de otros. Dicen que ellas mismas, cuando ya son muchas en el panal, se dividen y un grupo - al que encabeza una reina- inicia la formación de otro nido. El panal es como un pueblo, como una casa, tiene cuartos. Se divide y multiplica.

Otros testimonios también nos hablan de este sentido de totalidad, de colectividad social. En ellos es recurrente la referencia al trabajo de una colectividad y a la jerarquía entre quienes comparten dicho trabajo en tanto miembros de la comunidad, por ejemplo: "El iurixo (la capilla de la Virgen) es como el panal, aquí todos venimos a trabajar y a hacer lo que nos toca”. Así lo refirió uno de los encargados de la organización del culto a la Virgen de la Inmaculada en el pueblo serrano de Angáhuan, en ocasión de la celebración de la Semana Santa (marzo 2008). ${ }^{15}$ En esta celebración un par de panales y mancuernas de maíz forman parte de la ofrenda que es colocada según la secuencia de la representación de la Pasión de Cristo: primero se ubican al pie de la cruz donde Jesús es crucificado, luego en uno de los extremos del Santo Sepulcro donde permanece al momento en el que cambian la imagen de Cristo yaciente por la que representa al Señor de la Ascensión. Aunque la colecta de estos panales sea una labor ardua, los cargueros tienen por seguro que alguien se hará cargo de esta tarea; el destino de los panales tampoco es muy visible, pero se sabe que se los llevarán quienes los necesiten más o gusten de ellos.

Este sentido de colectividad conformada a partir de la socialización del trabajo y la jerarquía también ha sido referido por varios panaleros del pueblo de Cherán, al explicarnos lo que es el panal o lo que éste representa, en configuraciones diversas: "El panal es

${ }^{15}$ Una parte de esta celebración tiene lugar en la capilla de la Virgen -iurixo- que se encuentra a un lado del templo del pueblo. En el iurixo, la organización del culto recae en un cuerpo de autoridades nombradas por la comunidad que son renovadas año con año. 
como una familia", "el panal es como un pueblo", "el panal es como una casa, así mańana tú haces esto" le dijo un panalero a su hijo. Este sentido lo confirmamos al observar la manera en la que los panales se integran a un intrincado tejido de relaciones a través del cual fluye el intercambio de bienes y trabajo que sustenta la organización comunitaria para el ceremonial.

El panal congrega: cuando llega el momento de compartir el panal, la familia se agrupa para comer las larvas y la miel. El panal está también relacionado con la fertilidad y lo que da continuidad a la vida. Los jóvenes que se inician como panaleros, recibirán el reconocimiento por parte de la comunidad por haber cumplido con una de las obligaciones del ciclo ritual. La colecta de panales y la participación ceremonial es también una acción de cortejo, ya que además del reconocimiento público, recibirán el de las muchachas casaderas o de la novia; ellas, en señal de reconocimiento, les entregan una servilleta bordada que el panalero habrá de colocar en su katárakwa. ${ }^{16}$

San Antelmo, ${ }^{17}$ como mediador entre los panales y la comunidad, también es la imagen religiosa a quien se le presentan ruegos por ejemplo, para concebir un hijo varón, lo cual explica la participación de niños pequeños en este complejo ceremonial. Los niños, algunos apenas en sus primeros pasos, acompañan a sus padres y ofrecen vino a hombres y mujeres en un pequeño vaso; a ellos se le viste con los distintivos de los cargueros (sombrero, morral, gabán) y son quienes, en nombre de sus padres, agradecen al santo y hacen público el favor que de él recibieron.

Existen variaciones locales de este ceremonial a lo largo y ancho del P'urheecherio, lo que se traduce en diversas prácticas y testimonios, por lo que es claro que estamos frente a un complejo en el que

${ }^{16}$ La katárakwa es el armazón en el que actualmente se colocan los panales en la ceremonia del Corpus, pero es mucho más que eso, como se verá más adelante en el apartado 3.

${ }^{17} \mathrm{Al}$ patrono de los panaleros también le llaman San Anselmo. Los testimonios recabados entre la gente de mayor edad, así como las características de la indumentaria de las imágenes de este santo que pertenecen a familias del pueblo de Cherán, apuntan a que se trata de San Antelmo a quien también se refieren como San Telmo o San Telmito. En años recientes, uno de los párrocos designó el 21 de abril como el día dedicado a esta imagen, identificándolo así como San Anselmo, lo cual complica aún más una aclaración puntual. Ambos nombres refieren a las mismas imágenes religiosas. 
se expresan códigos comunes o compartidos que posibilitan la inteligibilidad de sentidos de las mismas, como la asociación con el ciclo de vida, con la organización comunitaria, con el conocimiento de sus territorios, con el carácter petitorio del ritual en el que se expresa una asociación significativa entre la lluvia y la fertilidad.

\section{LOS SABERES SOBRE LAS UAUAPU Y SUS RELACIONES CON OTROS ANIMALES Y EL AMBIENTE}

El estudio del Complejo Uauapu nos permite ahondar en la relación fundamental que el pueblo p'urhépecha establece con los cerros, con los bosques y todo lo que ellos contienen. Éstos, además de ser importantes fuentes de provisión de bienes para el sustento de los pueblos, son el lugar donde se encuentran los manantiales, sitios vinculados al origen de los pueblos; allá están las yácatas (o pirámides) y allá residen sus ancestros, de allá proceden recursos naturales que son integrados en la alimentación, en la curación y en el intercambio a pequeña escala. De los árboles obtienen leña. Proveen plantas como las orquídeas, por ejemplo, la arhurakua (Cattleya citrina), el cirimo, la flor de San Miguel, el nurite, entre muchas otras, que tienen un papel importante en las ofrendas a entidades sagradas en distintos momentos del ciclo anual. Por ello, los cerros tienen una dimensión sagrada que también explica el por qué de la distinción de género, lo cual es importante al momento de cumplir con ciertas obligaciones y prescripciones que marca el orden social y, particularmente, el ceremonial.

Con los cerros y lo que en ellos crece y reside, los p'urhépecha establecen estrechas interacciones que se expresan en la vida ritual, pero también en un sistema de creencias en las que el orden de lo no humano tiene un papel rector. Es así que la cacería y la recolección no son, o no de manera exclusiva, actividades de subsistencia o económicas. Son prácticas a través de las cuales se han generado, transmitido y decantado los saberes que forman parte de la visión del mundo, la vida social y el quehacer de este pueblo.

En los conocimientos y explicaciones sobre las uauapu y los panales se hace presente, ineludiblemente, el entorno natural. En ellos 
predomina un carácter relacional, sustentado en las interacciones de la gran diversidad de especies animales y vegetales, pero también de las características del medio físico: cerros con laderas suaves o escarpas pronunciadas, cañadas, malpaíses o derrames de lava, manantiales. Relaciones de coexistencia, de depredación, de competencia o beneficio mutuo cuya identificación se basa en la observación cuidadosa del comportamiento de los animales, de la distribución y cualidades de las plantas, de su relación con el medio ecogeográfico.

En el caso particular de las uauapu, se reconoce su gran importancia en la polinización de plantas silvestres y cultivadas. A diferencia de las relaciones que las uauapu establecen con otros animales y que suelen identificarse como favorables, hay claras relaciones de depredación por parte de muchos animales de la región como son el tecolote (Bubo virginianus); el pájaro carpintero, tsurheku o tsorheki (Dendrocopus villosus); un pájaro de pecho rojo conocido como charapopu; el ave denominada en p'urhépecha uanapu ajtí, nombre que se traduce como "comedor de uauapu" (Icterus galbula albelei) conocida también como calandria o "tortilla con chile" (Argueta 2008, 237); y los lagartijos. Incluso el coyote o jiuatsi (Canis latrans) llega a comer las larvas del traspanal. ${ }^{18}$

A consecuencia de la erupción del volcán Parícutin, ocurrida en 1943 , West $(1948,50-51)$ reporta que fue una época en la que escasearon los panales. Dice que los panaleros y la obtención de miel silvestre era una actividad muy importante antes de ello, sobre todo en tres comunidades: Cherán, Urapicho y Tanaco (Argueta 2008, 139), pero que el depósito de gruesas capas de ceniza volcánica y el aumento de la temperatura, produjeron cambios sustanciales en la

${ }^{18}$ Una persona de Angáhuan nos refirió que el coyote es de los animales más astutos y a ellos se les debe respeto. Los coyotes tienen habilidades para cazar haciendo uso de su capacidad de hipnotizar y controlar a la presa. Para el caso de los panales, sobre todo los anidados en oquedades del suelo conocidos como traspanal o talpanal (que aunque no tienen miel y las abejas pican fuerte, son muy apreciados por la cantidad y calidad de las larvas), nos describieron cómo el coyote introduce su cola por el agujero en el piso provocando que las avispas se adhieran a ella. Luego de un rato corre distanciándose del lugar y agitando su cola en movimientos circulares regulares, para ahuyentar a las avispas. Una vez que éstas se han desprendido de su cola, el coyote regresa por su preciado alimento, las larvas del traspanal. 
vida de los bosques y de la actividad agrícola. La disminución señalada, a decir de algunos panaleros, fue temporal ya que pronto volvió a haber panales, pues las uаuарu se fueron pero volvieron "porque son de aquí y siempre van a volver", nos dijo un joven migrante de Cherán, y siempre buscan dónde anidar.

Hoy en día, los principales problemas que hacen más difícil encontrar los panales son dos: los incendios forestales y las condiciones de deterioro de los bosques por la enorme tala de los árboles grandes. Durante los últimos años, según nos han dicho, ha sido difícil encontrar panales cerca de los pueblos ya que el bosque está muy mermado por los dos problemas ya señalados. La práctica de ir más lejos a traer panales propicia, a decir de ellos, que vuelvan a anidar en áreas cercanas al pueblo, incluso lo hacen en los muros altos de las casas. Las que no siguen este patrón son las que hacen panales rojos, característicos de la tierra caliente "a esas no les gusta quedarse por acá... mejor se regresan”.

\section{EL COMPORTAMIENTO DE LAS UAUAPU Y LA OBTENCIÓN DE LOS PANALES}

En estrecha relación con el conocimiento y el manejo de las características del medio físico, del conocimiento sobre los insectos sociales que aquí nos ocupan y la experiencia en la búsqueda y corte de panales, se han generado distintas estrategias para bajar los panales. Dos son las maneras más recurrentes de ubicar los panales: la observación de las abejas al vuelo y la identificación directa pendiendo de un árbol o de una pared rocosa.

Avistar al vuelo a las uauapu es la estrategia que comúnmente refieren quienes salen en busca de panales. ${ }^{19}$ La hora del día indica el alejamiento o retorno al panal: "por eso es mejor ir en la tarde" que es cuando suelen regresar y la luz permite verlas entre los árboles con mayor facilidad. Hay sitios que son especialmente útiles para la bús-

${ }^{19} \mathrm{El} D G(1991,690)$, ofrece el término Vauapu arihuani (oxear a los mosquitos) y Velásquez $(1978,220)$ da el termino de uauáp ukorheni (abejar), para describir la búsqueda del rastro de las uauapuecha en campo abierto o en la montańa. 
queda: "nos acercamos donde haya algún charquito o les ponemos un poquito de agua para que se acerquen y ya de ahí las seguimos". Entre los mismos panaleros se reconoce a aquellos que destacan por sus habilidades para ubicar a las uauapuecha; incluso se dice que hay quienes identifican cuando ya han comido o llevan entre sus patas materia prima para elaborar sus nidos, lo cual es seña inequívoca que regresan al nido.

Los mejores momentos para la búsqueda de los panales es la temporada del inicio de lluvias. En el pueblo serrano de Angáhuan se dice que la temporada de lluvias es la mejor para localizar los panales ya que el uinumu (las acículas u hojas de los pinos) al mojarse se juntan y deja ver mejor entre las ramas. El panal resiste muy bien la lluvia y es el tiempo cuando los panales empiezan a tener más miel.

Otros nos dijeron que prefieren salir en día nublado, porque así aunque las uauapu vuelan alto, es más fácil distinguir los puntitos negros, los cuerpos de las uauapu, contra lo blanco de las nubes. Por el contrario, cuando se sale en día soleado al hacer el avistamiento, "si se llega a ver el sol directo, cuando se voltea para abajo, se ve todo oscuro".

La otra forma, que es el encuentro directo con un panal, en un árbol o roca no es fácil pues hay que caminar mucho. Cuando se encuentra uno son cuidadosos en identificar la dirección de la entrada del panal a la que también conocen como ojo. Muchas veces la posición de la apertura del panal indica la dirección en la que se encuentra otro panal, "uno está viendo a otro, así mero es". Los panaleros de mayor edad comentan que cuando hay dos panales muy cercanos entre sí, estén o no en el mismo árbol, sólo debe cortarse uno de ellos.

Dicho procedimiento nos habla de las normas y prescripciones que distinguen a un buen panalero, ya que favorecen la conservación de las uauapu. No respetar este principio, conlleva riesgos pues dicen: "unos no sabían esto y así les fue" haciendo con ello referencia a los que llegan a accidentarse al resbalar o caer de un árbol, durante la labor del grupo en la jornada de colecta.

El procedimiento que realizan los panaleros al llegar a un panal, no es el de cortarlo inmediatamente, sino el de tocarlo y darle pequeńas palmaditas alrededor para que las uauapu se vayan saliendo del 
mismo, "para que se cambien de casa", "para que se enjambren y se reproduzcan", ésta es otra de las prescripciones que tienen los grupos de panaleros para hacer posible la reproducción de los panales.

Adicionalmente, hay que señalar que ambas formas de ubicar los panales también están relacionadas con la suerte; esta ventaja no se concibe como algo aleatorio, es una cualidad particular de algunos jóvenes, que va más allá de la destreza para ubicar los panales, que se devela y reconoce entre los miembros del grupo. Esta "suerte" o "ventaja” implica, de algún modo, una relación particular entre la persona y las entidades que dominan el ámbito del cerro y de los animales.

\section{LOS PANALEROS ¿CAZADORES O RECOLECTORES?}

Esta pregunta nos ha perseguido en nuestros recorridos y registros en campo. Con claridad reconocemos que la búsqueda y corte de los panales es una actividad que requiere de habilidades que son afines a la cacería. Apuntalamos esta afirmación en los conocimientos que los panaleros tienen sobre el comportamiento de las uauapuecha y que hemos expuesto en el apartado anterior, tales como las estrategias para avistarlas entre los árboles; las habilidades para seguirlas al vuelo o cuando se acercan para beber agua en algún arroyo o charco e incluso ponerles agua en algún cacharro a manera de trampa, prácticas similares al rastreo que hacen los cazadores con el venado o axuni (Dama virginiana sinaloe) o los conocimientos sobre su distribución y las características de sus nidos. Lo que nos hace dudar es que, en este caso, la finalidad no es el sacrificio de la presa, distintivo de la cacería, sino la cosecha, como en las actividades de la recolección vegetal. Conversando con Ismael García Marcelino, en Ihuatzio su pueblo natal de la región lacustre, le preguntábamos si el panal es animal o es vegetal: "es las dos cosas". Esta contundente respuesta la podemos extender a los panaleros que, de algún modo son cazadores, pero también son recolectores.

$\mathrm{Al}$ respecto, los panaleros son enfáticos en señalar que es muy importante propiciar que las uauapuecha abandonen el nido, tanto al momento de cortar el panal del árbol o al bajarlo de un risco, como cuando llega el momento de acomodarlos y exhibirlos en sus vistosas 




Fото 3. Polluelo de ¡̨águila? y abeja en interacción.

katárakwas. Dos son las razones principales cuando golpean suavemente la pared externa del panal: para evitar picaduras y para que salgan y vuelvan a enjambrar haciendo otro o más nidos. ${ }^{20}$ Asumen que el hecho de colectar panales, no va en detrimento de las uauapuecha, sino por el contrario, favorecen la subdivisión del enjambre. Si bien no hemos podido documentar con precisión si el panal es considerado un elemento animal o vegetal, el hecho de que se dis-

${ }^{20}$ Durante el tiempo en el que están armando sus katárakwas y seleccionando los panales, es común ver el revolotear de las abejas que, de un momento a otro, se concentran en alguna planta o rincón del techo de la casa, y ya de ahí se van a buscar donde anidar. Las que salen días después de haber cortado el panal son las que pasaron del estadio de larva a abeja, "son las más nuevas". 
tinga que éste tiene ombligo, ojito o que se asocie a la vagina podría llevarnos a pensar en que es concebido como animal. De ser así, la duda entre si los panaleros son cazadores o recolectores se aclararía, sin embargo no debemos dejar de lado la importancia que tiene, en su práctica ceremonial, la recolección de otros frutos, plantas y flores y el intercambio que de ellos se hace en el contexto de la celebración del Corpus Christi. En el caso de Cherán, otros animales que traen del cerro son, generalmente, presas que llevan vivas para - eventualmente- reincorporarlas a su medio; las atrapan e integran a su respectiva katárakwa mostrando, a través de ellas, las habilidades en el manejo de aquel espacio.

\section{LOS PANALES Y EL SISTEMA DE INTERCAMBIO CEREMONIAL}

La celebración del Corpus Christi es una de las constantes que encontramos en la mayoría de pueblos de la región p’urhépecha. En esta celebración, cuyo símbolo central es Cristo en la Eucaristía, participa el mayor número de imágenes religiosas de cada comunidad (de barrio, de oficio y otras al cuidado de grupos del culto local), sin estar dedicada a alguna de ellas en lo particular. El intercambio al interior de una misma comunidad y entre vecinas, la representación de oficios, la integración de espacios diferenciados (barrios, pueblos, cerro) y el Corpus, la pieza musical que acompaña los recorridos por el pueblo y que es exclusiva de esta celebración, son cuatro de sus elementos destacados. ${ }^{21}$ No obstante, el calendario litúrgico marca su celebración a los 60 días del Domingo de Resurección, en los pueblos de la región hay adecuaciones locales en función de una secuencia definida por un sistema de visitas recíprocas.

${ }^{21}$ Ismael García Marcelino, de Ihuatzio, comenta que la pieza musical conocida como el Corpus corresponde a la categoría de "torito", que es una forma particular de los abajeńos; se distingue de éstos en el hecho de que los "toritos" sólo se ejecutan al tiempo que se desarrolla alguna acción específica de carácter ceremonial, como sería el momento de depositar una ofrenda, el curso de alguna procesión o recorridos con autoridades (Comunicación verbal, 2009). Aunque con ciertas variaciones locales en la melodía, esta pieza, de manera similar a aquella que se ejecuta en ocasión de la Danza de Moros, es la que hemos registrado de manera recurrente a lo largo y ancho de la región. 
La recurrencia de estos elementos permite, a su vez, identificar importantes variaciones locales en términos de la organización del ceremonial y de las particularidades de las formas diferenciadas del trabajo que se representan ritualmente, por lo que también se conoce como "la fiesta de los oficios", entre los que siempre están presentes los agricultores. Éstos son pueblos en los cuales la pluriactividad es una característica clara de las estrategias de reproducción de la vida familiar, pero, cuando el Corpus llega, se impone la necesidad de tomar la decisión en torno a la integración en sólo uno de los grupos que participan en la fiesta. Por su relación con el calendario agrícola, el Corpus está asociado al inicio de la temporada de lluvias y, según la costumbre local, al tiempo de la siembra o la primera escarda.

La mayor parte de los oficios que se hacen presentes tienen correspondencia, más o menos directa, con los que desempeñan los pobladores de cada pueblo para su sostén económico, pero también hay oficios que tienen un papel estrictamente ritual: los cazadores y los panaleros. Unos y otros ocupan espacios que, en ocasiones, comparten con los agricultores, pero a diferencia de este grupo en el que también participan mujeres, los panaleros y los cazadores son grupos formados exclusivamente por hombres jóvenes y adultos. A esta distinción se suma la de los espacios involucrados en el cumplimiento de las funciones que asumen en la organización del Corpus y que, implican -necesariamente- el traslado a los cerros próximos y distantes de sus respectivos pueblos de residencia. Allá, además de cazar o apresar animales, colectar plantas y flores que integran a las ofrendas, también ubican y cortan un pino largo aunque no de gran diámetro. Limpian el tronco y lo trasladan al pueblo como parte de este ceremonial. Antes de levantarlo, en el centro del atrio o de la plaza, le colocan un panal, dinero y regalos que obtendrá quien logre trepar este palo encebado al que también nombran panal.

Si bien es recurrente identificar la presencia de los panales en las celebraciones de distintos pueblos vemos que, a juzgar por la cantidad, su importancia es variable entre ellos. Así, por ejemplo, en Zipiajo hemos observado que cuelgan algún panal en las capillas efímeras que construyen en las cuatro esquinas del atrio, representando a cada uno de sus barrios; el hombre que acompańa al grupo 
de sembradoras también suele llevar un panal. En Comachuén, nińos o jovencitos asumen la obligación de entregar panales a los cargueros de los oficios que levantan sus respectivas capillas pozas. En Uricho, los cargueros colocan un panal en la espalda de la imagen conocida como el vicario de San Francisco, que es la que acompaña a la procesión. En estos pueblos, aunque los panales apenas son unos cuantos, revisten gran importancia si atendemos a los lugares donde son colocados, a la relación con la ofrenda presentada por otros oficios o a las personas que los portan en los recorridos por el pueblo y al momento de la procesión. En Cheranatzicurin, dice Pedro Márquez, durante la Ch'anatskua se le colocan varios khuipu en la espalda a las esposas de los oficiales del templo (Comunicación personal, 2009). En Cocucho y en Charapan, por ejemplo, los dos grupos que encabezan la procesión son los cazadores (también llamados venaderos o tiradores) y los panaleros. ${ }^{22}$ Detrás de ellos van los labradores y el resto de los oficios (carpinteros, albañiles, bordadoras, panaderos, músicos, apicultores) representados en esta celebración.

\section{Alianzas y Competencias entre panaleros: prestigio Y RECONOCIMIENTO SOCIAL A TRAVÉS DE LOS PANALES}

En el apretado ciclo ritual del pueblo de Cherán, la Bajada de los Panaleros es uno de los momentos más esperados. En este pueblo serrano, la participación de los panaleros está basada en una organización específica que involucra un cuerpo de cargueros de cada uno de sus cuatro barrios, con sus respectivos acompañamientos. ${ }^{23} \mathrm{La}$

${ }^{22}$ Entre los mayas, al dueño de los venados se le llama zip-término que hace alusión a pecado o falta-, que es un venado pequeño que lleva entre sus cuernos un panal de avispas (Ella F. Quintal, Comunicación personal, 2009). En la celebración del Corpus, en algunos pueblos del sur de la península, panales y ramilletes de flores forman parte sustancial de las ofrendas. Una composición similar la registramos en el pueblo de Charapan (2008): un pequeño panal fue atado entre la cornamenta de un venado disecado que acompańaba a una de las agrupaciones de cazadores.

${ }^{23} \mathrm{El}$ acompańamiento en los pueblos p'urhépecha constituye una compleja red de relaciones centrada en la figura del carguero. Alrededor de él participan, de acuerdo a relaciones de parentesco, de género y generación, un número variable de miembros de la comunidad que harán posible, mediante un sistema de ayudas mutuas, el cabal cumplimiento que esta autoridad de la jerarquía religiosa local debe garantizar ante la comunidad y ante la divinidad. 
participación de los panaleros y la alianza con alguno de los cargueros o imágenes del santo patrono se hace más intensa durante la semana previa al miércoles marcado como la víspera del Corpus. Durante ese tiempo el carguero y su familia se trasladan a una de las orillas del pueblo, a lugares donde marcan el umbral entre el cerro y el pueblo, para instalar un ranchito. ${ }^{24}$ Allá llevan la imagen del santo patrono a su cargo; allá duermen, allá comen; allá pasan los panaleros, ya sea antes de salir al cerro, a la búsqueda de más panales; ahí le piden su protección y ayuda para encontrar y bajar los preciados panales; y allá regresan para entregarle, a manera de ofrenda, alguno de los panales de menor tamaño.

Un día antes de la celebración del Jueves de Corpus, conforme lo marca el calendario litúrgico, empiezan a preparar sus katárakwas y se alistan para acompañar a los cargueros para subir al Calvario y de ahí, luego de bailar, bajar al centro del pueblo, por lo que el nombre con el que se reconoce esta fase de la celebración es precisamente la Bajada de los Panaleros. A juzgar por los testimonios que hemos registrado y lo que está reportado en la literatura, la participación de los panaleros en la celebración del Corpus ha ido acrecentándose con el paso de los años. Hacia 1940, Beals reportó la existencia de dos grupos de panaleros, cada uno con su respectiva imagen del santo patrono y encabezados por los cargueros, uno por el barrio de arriba y otro por el de abajo (Beals 1992, 307). Actualmente se forman cuatro grandes grupos que corresponden a igual número de barrios en los que está subdividido el pueblo, encabezados por sus cabildos o cargueros y la imagen del santo patrono que se mantiene a su cargo a lo largo del año. Existe otra pequeña imagen que pertenece a una familia; a ésta se le reconoce precedencia del resto: "es mero el patrón".

Subir al cerro, formar parte de un grupo, hacer la colecta de plantas, la búsqueda y el corte de panales y cazar animales son actividades que transcurren entre diversión, risas y enseńanzas entre los

${ }^{24}$ Beals, con base en información recabada en entrevistas, señala que para la década de los años de 1940 había dos imágenes, una por cada barrio y sólo se instalaba un ranchito, el de Cosumo (1992, 307). 


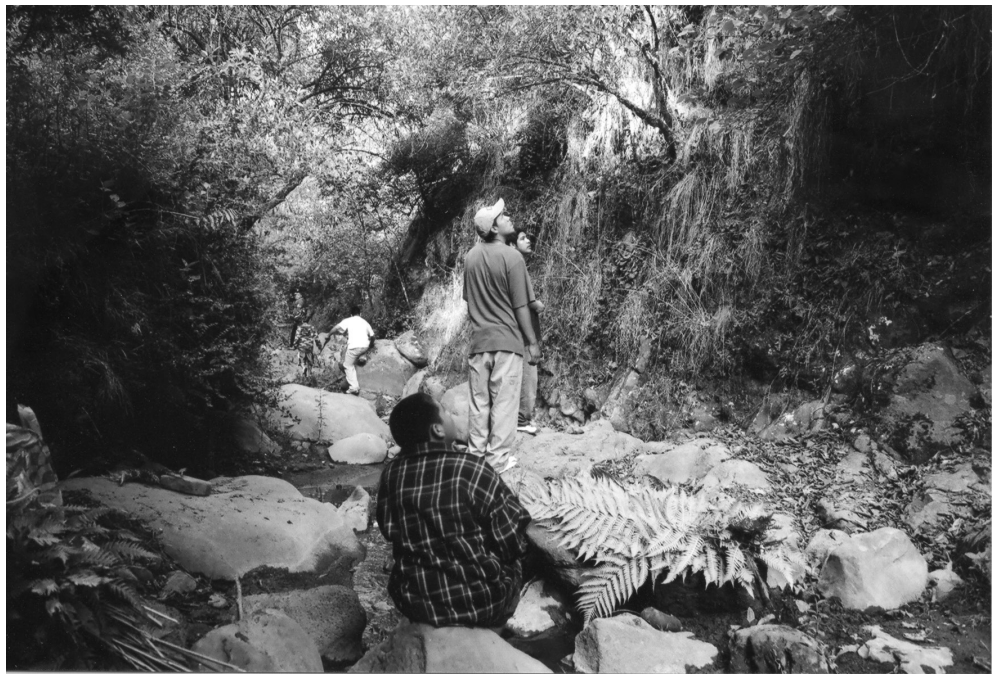

Foто 4. Colecta de hojas de cirimo y helechos para armar la katárakwa.

miembros del grupo. Los más experimentados dirigen y retan a los que se van iniciando, cuyas edades oscilan entre los 12 y los 14 años. Los conminan a trepar por las paredes de las cańadas o a los árboles indicándoles por donde hacerlo y, a la vez, retándolos cuando muestran temor, duda o dificultad de hacerlo. Lo hacen en medio de risas y bromas que suben de tono, incitándolos constantemente a arriesgarse aunque siempre se mantienen vigilantes, les indican hacia dónde trepar y cómo hacerlo, pero también provocan su hombría diciéndoles "a poco te va a dar miedo", "ni que no pudieras cortar esa rama”, "aviéntate hombre, no seas...”.

Al cortar las ramas de cirimo (Tilia occidentalis) y del helecho (Polypodium arcanum bakeri) van teniendo claro el uso que se les da a estos recursos, por lo que hacen una selección cuidadosa para garantizar la buena hechura de la katárakwa, lo que no sólo implica hacer gala de un gran tamaño, sino una construcción adecuada para sostener el mayor número de panales y de los otros elementos que la conforman. Es común que mientras colectan otros de los elementos que requieren para la construcción de las katárakwas, silben 
el son del Corpus, la pieza musical que distingue a esta celebración y que es ampliamente conocida en los pueblos de la región. Es también un tiempo lúdico altamente apreciado en este pueblo lo que, sin duda alguna, es un factor que explica la vigencia y relevancia de este ceremonial.

La integración de grupos de panaleros involucra relaciones de parentesco, vecindad y amistad y si bien en ellos participan hombres de distintas generaciones, los jóvenes son franca mayoría. La formación de grupos de panaleros sigue dos principios -el residencial y el de parentesco-que, de alguna manera, también corresponde al de la obligación para con alguna de las imágenes del santo patrono y de acompañamiento de alguno de los cuatro cargueros en turno.

Siempre hay una primera vez para ir al cerro y formar parte de estos grupos, incorporación que, como parece claro, puede considerarse un ritual de paso. Un proceso a través del cual el muchacho además de adquirir estos conocimientos y destrezas para trepar a los árboles, a las paredes de las cańadas, reconocer los caminos y veredas, los habilita para formar parte de un grupo poniendo a prueba las habilidades y valentía para conducirse. Pero sobre todo, lograr el reconocimiento frente a la comunidad al cumplir con una de las tareas de este importante ceremonial: bajar panales, integrarse a algún grupo, aprender normas, conductas, adquirir habilidades en el manejo del entorno del cerro, cumplir a la comunidad participando en el Corpus. Dice uno de los mayores: "a ellos les ponen pruebas muy trabajosas y tienen que entrarle a todo incluyendo la borrachera".

La participación de los panaleros en el contexto de la celebración del Corpus también tiene un sentido propiciatorio: con su participación, establecen un vínculo con la divinidad y con la naturaleza que favorecerá un buen temporal, lo cual explica el por qué la Bajada de los Panaleros es aún más festiva cuando se da en medio de una lluvia fuerte y prolongada.

La formación de los grupos de panaleros tiene una doble finalidad: construir una katárakwa y agruparse entre ellos para acompañar al carguero que corresponda en razón del lugar de residencia y de las relaciones de amistad. Se es parte de un grupo por el gusto de 




Fото 5. Armando la katárakwa.

ir a colectar, "aquí nadie nos manda, vamos porque nos gusta la miel y los gusanitos y mero pues andar en el cerro. Todo el tiempo es bonito, cuando niños y jóvenes, con el papá o con el abuelo. Mi abuelo, nos decía un panalero del barrio primero, iba tocándoles el son del Corpus a las abejitas cuando salía a buscar panales". Pero además del gusto, hay la certeza de que se necesita mucha habilidad y suerte para encontrar los panales. Se inician en estas tareas de manera directa al integrarse a algún grupo "entre ellos se van enseñando", pero se reconoce que además se requiere de habilidades que no todos tienen. Ello no excluye las enseńanzas que fluyen de padres a hijos en éste y otros ámbitos de la vida cotidiana. 
La katárakwa es una estructura construida con dos largos y delgados troncos que, entrecruzados, se fijan con delgadas tiras de madera. ${ }^{25}$ Esta estructura dará sostén a hojas y flores de distintas plantas, que los propios panaleros salen a recolectar, así como los panales y animales que hayan apresado en sus recorridos; sostiene también aperos de trabajo como lazos, azadones, hachas o machetes y otros elementos asociados al oficio como el bule de donde toman agua, el gabán y el sombrero. Las katárakwas llegan a sobrepasar los tres metros de longitud y su peso oscila entre los 60 y los 80 kilos.

Para elaborar una katárakwa, se juntan entre cuatro y ocho hombres jóvenes entre quienes hay relaciones de parentesco o vecindad; es común que en el grupo, de manera un tanto marginal, participen señores de mayor edad y experiencia. La formación de estos grupos es flexible y al interior de cada uno las relaciones son múltiples; ello explica que siempre haya niños de menos de 10 años que son hermanos o hijos de panaleros mayores. A su vez, varios de estos grupos -entre 5 y 8 - se juntan para participar por familia, calle o barrio para integrarse a otro grupo mayor que irá acompańando a alguno de los cuatro cargueros de los barrios de Cherán; cada uno de estos grupos mayores llega a conjuntar entre 30 y 40 katárakwas, es decir, llegan a participar entre 120 y 160 katárakwas.

El cabildo, término con el que distinguen al carguero en turno de cada barrio, tiene conocimiento de estos grupos, ya sea porque los han ido a invitar con antelación o porque los propios panaleros les hacen saber que ellos los acompañarán en los recorridos por el pueblo. Aunque la norma señala que los panaleros se agruparán en torno al carguero de su respectivo barrio, esta adscripción suele ajustarse en función de situaciones concretas. Es el caso, por ejemplo, de que los cabildos, apelando a relaciones de parentesco o afinidad, llegan a competir por los panaleros más prestigiados, relegando la adscripción barrial. Así, cada uno de los cuatro cabildos -uno por cada barrio- se presentará con sus panaleros. Cada carguero siempre buscará ser el que llegue acompañado de un mayor número de pa-

${ }^{25}$ Uno de los sentidos de este término alude a una estructura cuya finalidad es la de cargar y sostener y a ella se amarran diversos elementos que sea menester transportar. 
naleros y de las más vistosas katárakwas, ya que eso le confiere reconocimiento por parte de la comunidad.

Entre los miembros del grupo se generan relaciones muy diversas que obligan a acatar o adecuar ciertas normas que son, en mayor o menor grado, conocidas y respetadas por quienes forman parte de un grupo de panaleros. Se establecen relaciones múltiples: de solidaridad, de complicidad, de reto y también de venganza. A veces uno ve un panal grande, pero "uno le saca por estar muy alto y mejor te pasas sin decir nada para que no te digan que eres rajón". Otras veces, se le dice a alguno de sus compañeros que tiene más habilidad de trepar. El hecho de localizar el panal con la vista, le da más derecho para asegurarlo como propio; y puede o no recibir ayuda para trepar y cortarlo, pero el panal será para quien lo avistó primero.

El área de colecta no se restringe al área boscosa -cubierta de pino y encino- ni a las cañadas o áreas de matorral o del malpaís que pertenece a la gente de Cherán, sino que se extiende a otras poblaciones vecinas y distantes. Entre los panaleros hay un amplio conocimiento de los caminos, en medio de los cerros, para llegar a las áreas donde hay mayor cantidad de panales. No hay duda de que esta actividad coadyuva en la generación de sus propios mapas, parámetros y referencias con base en los cuales harán las decisiones sobre los lugares hacia donde habrán de dirigir sus pasos llegado el momento de iniciar la colecta de panales, flores, plantas y la cacería de animales. Según sea la distancia, recorren el trayecto a pie o en vehículo. Estas tareas implican también ciertas normas que los panaleros saben reconocer: cortar panales en cerros que no pertenecen al pueblo requiere, sobre todo en el caso de pueblos vecinos, la solicitud de permiso ante las autoridades comunitarias en turno.

Es común escuchar que años atrás, entre los panaleros, había acuerdos implícitos y de respeto mutuo: quien veía primero un panal, ponía una seña en el árbol correspondiente -un lazo amarrado o una marca en la corteza- por lo que nadie más podía cortarlo. Hacían esos recorridos con meses de anticipación, con la confianza de que aquel panal habría de respetarse; días antes de la fiesta, y que lo bajaría el panalero que lo marcó. El tiempo que transcurría entre el señalamiento del árbol y el corte del panal favorecía su crecimien- 
to y garantizaba exhibirlo en buenas condiciones. ${ }^{26}$ Algunos panaleros comentan que cada vez es más difícil dar vigencia a estos acuerdos, por lo que los panaleros que ven un panal lo bajan. También por esta razón no pueden salir con mucha anticipación, ya que si cortan el panal con antelación la miel empieza a minarse por las paredes y el panal se pudre por descomposición de las larvas.

También hay normas que orientan la formación de los panaleros: encabezará el grupo aquel que haya tenido la habilidad de localizar y bajar panales de mayor tamaño, a él le entregarán otros miembros del grupo, en señal de reconocimiento, diversos animales que hayan cazado para que los luzca en su katárakwa, entre ellos el águila (uacus) y el coyote (jiuatsi), ya que ello es señal de capacidad, habilidad y buena suerte.

Si bien no hay competencia entre poblados vecinos por los panales, en tanto que Cherán es el que destaca por la colecta profusa de los nidos, la competencia se da entre grupos de panaleros del mismo pueblo: la competencia genera prestigio ante la comunidad. ${ }^{27}$ Este prestigio también es importante en la relación que, en este espacio ritual, establecen los panaleros, sobre todos los jóvenes solteros, con las muchachas casaderas. Un joven panalero que, como muchos otros de este pueblo, habitualmente va a trabajar de manera temporal a los campos agrícolas de los Estados Unidos, afirmó de manera categórica que a él le gusta ir por los panales y bailar su katárakwa para "apantallar a las chavas"; el año anterior no pudo estar, pero en 2008 sí cumplió su promesa de volver.

${ }^{26}$ Pedro Márquez señala que esta norma, respecto al khuipu como objeto ceremonial y sagrado, recuerda la norma existente en el periodo precolonial sobre los venados como seres consagrados a Curicaveri. Como se narra en $R M$, los venados se avistan y se cazan, pero estando heridos, nadie podía tocar su piel y su carne más que el cazador. La ira de Ticátame, referida en $R M$ (p. 18) se produce cuando algunos pobladores ribereńos capturan un animal herido para comer su carne y hacen jirones la piel $(C f r$. Argueta 2008, 64).

${ }^{27}$ Esta competencia, que llega a manifestarse como rivalidad, la observamos también en la colecta de panales y traspanales que forman parte de la ofrenda a las ánimas en el pueblo de Tarecuato. Grupos de jóvenes van de una a otra casa, donde se ha erigido un altar para un familiar muerto durante los últimos ańos, para ofrecer sus panales a los padrinos y parientes cercanos del difunto. El encuentro entre ellos, en las calles del pueblo, llega a estallar en piques o peleas. 
LOS PANALES Y EL SISTEMA DE INTERCAMBIO EN EL CEREMONIAL

Los panales, de manera similar a otros bienes de uso ritual, ingresan a circuitos de intercambio en el que participan numerosos miembros de las comunidades en función del género, generación y posición que ocupan en la jerarquía religiosa local. En el caso de los panales, la mayor parte se distribuye en circuitos de intercambio definidos por la relación entre los panaleros y sus respectivos cargueros o cabildos de barrio y sus familiares más cercanos. Recordemos que cada grupo que participa en la elaboración de una misma katárakwa está formado -en promedio- por cinco miembros, por lo que cada uno de ellos replica esta forma de distribución.

En la víspera del Corpus, la pareja que funge como cabildo o encabezado de cada barrio inicia un recorrido para invitar a comer a los panaleros, lo que también implica el acompańamiento al Calvario y la bajada al centro del pueblo. Para refrendar el compromiso, el carguero ofrece trago de vino a los panaleros y alguno de ellos baila con la carguera. Los panaleros, en señal de reconocimiento, entregan un panal a la carguera de barrio; le entregarán otro más cuando, al día siguiente, regrese para agradecer su participación. A su vez, cada persona que recibe un panal, lo parte en porciones que distribuye entre los miembros de su familia, de ahí que el sentido del panal también es el de congregar. Adelaida Cucué comentó que "el panal junta a la familia [...] es un gusto cuando alguien llega con el panal [...] lo reparte de a pedacitos y ahí nos lo estamos comiendo. Chupamos la tecatita para llegar a la miel". Actualmente hay algunas familias que venden los panales durante la mańana del Jueves del Corpus, una vez que los panaleros han concluido con su participación ceremonial.

En este circuito de intercambio también fluyen las flores del corpus (Laelia speciosa alba) que la cabilda está obligada a dar a los panaleros que la acompañarán a El Calvario y que ellos pondrán en sus respectivas katárakwas. Los miembros de la familia de la cabilda son los encargados de recolectar esta flor en los bosques y áreas de malpaís cercanos. 




Fото 6. Los panaleros al llegar a El Calvario en la víspera del Corpus.

A lo largo de los recorridos, tanto en la víspera como en el Jueves de Corpus, diversas personas le presentan, a manera de reconocimiento, un canasto con fruta y otros bienes de consumo. De manera paralela, y durante los días que el carguero esté cumpliendo con la instalación del ranchito y la elaboración de la comida una vez que regresan al pueblo para prepararse para la Bajada de los Panaleros, un grupo numeroso de mujeres y de composición cambiante, se mantiene preparando los alimentos que habrán de ofrecer a los panaleros y a otras personas que lleguen a acompañarlos. Unas y otras son expresión de las ayudas mutuas que sostienen la organización del ceremonial; compromisos que se sellan cuando la mujer que ofrece o presenta la ayuda ata un listón de color en la trenza de la carguera. Portar un gran atado de coloridos listones, es muestra de la cantidad de gente que, como cargueros, los ha acompańado y con quienes se ha establecido o se mantiene vigente un compromiso marcado por la reciprocidad.

Otra vertiente del intercambio, que se lleva a cabo en la plaza del pueblo, es la de trocar sal de mar por productos elaborados para la 
ocasión y en forma de miniaturas. Son productos representativos de los oficios que participan en la celebración del Corpus. La sal, que se obtiene mediante este circuito del intercambio toma un valor particular en el caso de las xurhijki, mujeres curadoras; muchos de sus procedimientos de curación, requieren de manera central o secundaria, el uso de sal de grano, por lo que reservan la sal que obtuvieron en la celebración del Corpus para esos casos.

Otro aspecto del complejo sistema de intercambio que se activa en la Bajada de los Panaleros y la celebración del Corpus, es la presentación de un panal a manera de ofrenda junto con los dones que son recibidos por el cura párroco al oficiar la primera misa del día. Además de los objetos que constituyen la liturgia -las ostias y el vino- los cabildos del templo presentan con un sentido similar, fruta de la temporada y un panal. El panal, a decir de una de las autoridades de la jerarquía religiosa, se le concibe con cualidades similares a la ostia, es decir, es un alimento sagrado.

\section{REFLEXIONES FINALES}

El Complejo Uauapu tiene una importancia central en la vida ceremonial de las comunidades del pueblo p'urhépecha y hasta ahora ha recibido muy poca atención en los estudios regionales. Saberes y rituales como los descritos también hacen evidente la importancia que tiene el espacio del monte y los cerros para el pueblo p'urhépecha actualmente, tanto en la constitución de las comunidades en términos del aprovechamiento de los recursos naturales, como de las concepciones y maneras de entender y explicar el mundo y ubicar en él la vida de los p’urhépecha.

En términos del Modelo Kosmos-Corpus-Praxis (KCP) elaborado por Toledo (1992, 9 y ss) y Toledo y Barrera (2008, 113 y ss), el estudio del Complejo Uauapu nos ha mostrado los diversos puntos de unión relativos a esas tres esferas que logra condensar una sola especie, pequeña y aparentemente insignificante (a los ojos del fuereño), pero enormemente importante en el marco de una cultura que ha hecho de sus relaciones con las uauapu, un ceremonial, un saber ambiental y una dulce interacción. Esta especie mínima, nos 
muestra en su sencilla complejidad, un gran universo de interrelaciones y significados. Pero lo que consideramos parte del núcleo duro del KCP, si no es que el núcleo mismo, es la interrelación y la complejidad, pero sobre todo algo mucho más claro y diáfano -aunque nada sencillo de seguir y entender- que es el sentido ético de las relaciones entre pueblos como el p'urhépecha y la naturaleza. Más que los intercambios material y simbólico, consideramos que hay un enorme intercambio de sentidos éticos que dan lugar a normativas interiorizadas que se sustentan en un entramado social que deriva en comportamientos altamente ritualizados.

Si los panaleros son cazadores-recolectores, o uno u otro, y cualquiera que sea su caracterización, no tenemos duda en que la captura o la obtención de los panales tiene ante todo un carácter ritual que, definitivamente, nos recuerda la obtención de las pieles de venado en el periodo tarasco, las cuales servían como ofrenda y alimento a los dioses y que tiene su correlato en la cacería ritual de venado que se práctica actualmente entre el pueblo kikapú de Coahuila (Argueta, Embriz y Noria 1990, 50), o el huichol del Jalisco y Nayarit. Como lo hemos señalado en un texto anterior, para los p'urhépecha, como para el resto de las culturas de tradición mesoamericana, la naturaleza es una entidad sagrada, que tiene un carácter animado; es proveedora y condensa el sentido de la fertilidad (Argueta y Castilleja 2008). La naturaleza forma parte fundamental de la concepción del mundo entendida como "la visión estructurada en la cual los miembros de una comunidad combinan de manera coherente sus nociones sobre el medio ambiente en que viven y sobre el cosmos en que sitúan la vida del hombre" (Broda 2001, 16); concepción que guarda una estrecha relación con la manera en la que se rige y organiza la vida social.

La red que se entreteje entre la vida social, las acciones rituales y el entorno natural permiten ver el carácter eminentemente relacional que sustenta las formas de conocimiento del pueblo p'urhépecha, conocimientos en los cuales la distinción entre naturaleza y cultura, entre naturaleza y sociedad más que develarse de manera dicotómica, nos conduce a entenderla en sus relaciones e interacciones fundamentales. Es por ello que el registro de las cere- 
monias, conocimientos y actividades que compartimos con ustedes, y las dificultades al intentar un orden de exposición que no fragmentara o escindiera la información del complejo del que ésta procede, nos permite afirmar que la intensa interacción entre los pueblos indígenas y la naturaleza, sucede en un orden de cosas que difícilmente permite dicotomizarlos, por lo que nos proponemos explicarlo por la gran red de relaciones e interacciones que se establecen entre los ordenes humano y no humano, como lo han seńalado Descola (2001 y 2005) y otros autores, a través de interrelaciones que no parecen ser de naturaleza jerárquica.

La explicación de la indisoluble relación entre la vida social y el entorno natural va más allá de las múltiples y complejas interacciones que se tienden generando estrategias de producción y reproducción. Se expresa también en modelos de entendimiento en los que, por ejemplo, las formas y las cualidades reconocidas a ciertos animales y plantas constituyen referentes de primer orden para la explicación de la vida social, del transcurrir en el tiempo y del sentido de pertenencia a un mundo que no es exclusivamente humano. Por ello, coincidimos con lo expuesto por Franco quien, al hablar de la hormiga, establece analogías con la vida de los p'urhépecha $(1994,220)$. Se trata de analogías que, al ubicarse en un alto nivel de abstracción, constituyen modelos de explicación del mundo de una manera más integral que cuando se marca una distinción sustancial entre la sociedad y la naturaleza.

La observación e interacción con la naturaleza es una práctica directamente relacionada con la cosmovisión que ha permeado la historia de los pueblos a lo largo del tiempo, proveyéndoles no sólo de innumerables saberes, sino, sobre todo, de un sistema de conocimiento que no es ajeno al cuerpo de creencias, como tampoco lo es a las prácticas de uso múltiple de los recursos naturales que forman parte fundamental de sus territorios y que, al constituirse en bienes patrimoniales, posibilitan su reproducción social. Lo que puede deducirse del Complejo Uauapu es que los saberes y haceres se producen y transmiten en el contexto de la ceremonia, fuera de ese marco ritual el sentido de estas actividades podría ser sustancialmente diferente y en su ausencia, pensamos que es muy difícil que hubiese 
permanecido, con todos los cambios y modificaciones de por medio, hasta el momento actual.

La relación entre las modalidades del aprovechamiento de los recursos naturales y las concepciones del mundo son elementos constitutivos de un mismo proceso que forma parte del sentido y concepción de sus respectivos territorios (Nygren 1999; Durand 2008 y Argueta 2008). Las intrincadas relaciones entre ellos no son mutuamente determinantes, por lo que sus ritmos de cambio no se corresponden unos a otros de manera directa y unívoca.

\section{REFERENCIAS}

Alcalá, Jerónimo de, Relación de Michoacán, coordinación de edición y estudios Moisés Franco Mendoza, Zamora, El Colegio de Michoacán, Gobierno del Estado de Michoacán, 2000.

Anónimo(s), [1560-1561] Diccionario Grande de la Lengua de Michoacán, 2 tomos, Introducción, paleografía y notas de J. Benedict Warren, Morelia, México, Fimax publicistas, 1991, 704 + 848 pp. Argueta, Arturo, "Etnobiología y civilización mesoamericana", México Indígena, INI, núm. 24, año 4, septiembre-octubre, 1988, 17-23.

, Los saberes purhépecha. Los animales y el diálogo con la naturaleza, México, umsnh, unAm, Gobierno del Estado de Michoacán, uirm, pNuma y Casa Juan Pablos, 2008, 254 p. + ils.

Argueta, Arturo, Arnulfo Embriz y José Luis Noria, "Kikapú: cazadores rituales”, en México Indígena, núm. 11, agosto 1990, 49-52.

Argueta, Arturo y Aída Castilleja, El agua entre los p'urhépecha de Michoacán, en Cultura y Representaciones Sociales, Revista electrónica de Ciencias Sociales, Instituto de Investigaciones Sociales, unam, México, año 3, núm. 5, septiembre 2008, 64-87 (www.culturayrs.org.mx).

BeAls, Ralph, Cheran, un pueblo de la sierra tarasca, Zamora, El Colegio de Michoacán, 1992 [1945].

BrodA, Johanna, "Introducción”, en Johanna Broda y Feliz BáezJorge, Cosmovisión, ritual e identidad de los pueblos indigenas de México, México, Conaculta, FCE, 2001, 15-45. 
Castilleja, Aída, "La Cha'nantskua o fiesta del Corpus en pueblos purépechas", en Johanna Broda y Catharine Good, Historia y vida ceremonial en las comunidades mesoamericanas: los ritos agricolas, Colección Etnografía de los pueblos indígenas de México, Serie Estudios monográficos, México, INAH, 2004, 387-413.

, "¿A qué nos referimos cuando hablamos de la región purépecha?”, en Antropología, Boletín Oficial del Instituto Nacional de Antropología e Historia, México, núm. 64, Nueva época, octubre-diciembre 2001, 21-33.

Construcción social y cultural de categorías referidas al espacio. Un estudio en pueblos purépecha, Tesis para obtener el grado de doctor en antropología, México, Escuela Nacional de Antropología e Historia, 2007.

Descola, Philippe, "Construyendo naturalezas. Ecología simbólica y práctica social”, en Philippe Descola y Gísli Pálsson, coords., Naturaleza y Sociedad. Perspectivas antropológicas, México, Siglo XXI, 2001, 101-123.

, Par-delà nature et culture, París, Gallimard, 2005, 623 pp.

DURAND, Leticia. "De las percepciones a las perspectivas ambientales. Una reflexión teórica sobre la antropología y la temática ambiental”, Nueva Antropología, vol. xxi, núm. 68, enero-junio, 2008, 75-87.

FisCHER, Franz, "La apicultura en la economía de subsistencia de las zonas boscosas de sabana de Miombo en el Africa sud-central" en Red Forestal de Desarrollo Rural, www.odi.org.uk, febrero 2007.

Flachetti, Ana María y Guiomar NAtes-Parra, "Las hijas del sol: las abejas sin aguijón en el mundo uwa, Sierra nevada del Cocuy, Colombia”, en Astrid Ulloa, ed. Rostros culturales de la fauna. Las relaciones entre los humanos y los animales en el contexto colombiano, Colombia, Instituto Colombiano de Antropología e Historia y Fundación Natura, 2002, 175-214.

Franco, Moises, “Sïruki. La tradición entre los p'urhépecha”, en Relaciones. Estudios de Historia y Sociedad, núm. 59, vol. xv, 1994, 209-238.

Nygren, Anja. "Local knowledge in the environment Develop- 
ment discourse: From dichotomies to situated knowledges", Critique of Anthropology, vol. 19 (3), 1999, 267-288.

Sepúlveda, María Teresa, Los cargos político religiosos en la región del Lago de Pátzcuaro, Morelia, Morevallado Editores, 2003 [1974]. Swadesh, Maurice, Elementos del tarasco antiguo, México, unam, 1969.

Toledo, Víctor Manuel, "What is Ethnoecology?”, Etnoecológica, vol. 1, núm. 1, abril, 1992, 5-21.

Toledo, Víctor Manuel y Narciso BARrera, La memoria biocultural. La importancia ecológica de las sabidurías tradicionales, Barcelona, Icaria, 2008.

Velázquez Gallardo, Pablo, "Dioses tarascos de Charapan”, Revista Mexicana de Estudios Antropológicos, México, Sociedad Mexicana de Antropología, 1947.

, Diccionario de la lengua phorhépecha, México, Fondo de Cultura Económica, 1978.

West, Robert, Cultural Geography of the Modern Tarascan Area, Washington, Smithsonian Institution, Institute of Social Anthropology, Publication num. 7, 1948.

FECHA DE RECEPCIÓN DEL ARTículo: 18 de noviembre de 2010

FECHA DE ACEPTACIÓN Y RECEPCIÓN DE LA VERSIÓN FINAL: 11 de abril de 2011 